Liebscher, M; The Challenges of Editorship: A Reflection on editing the Jung-Neumann

Correspondence. Journal of Analytical Psychology (In press). Downloaded from UCL Discovery:

http://discovery.ucl.ac.uk/1472615.

\title{
ARTICLE
}

\section{The challenges of editorship: a reflection on editing the Jung- Neumann correspondence}

\author{
Martin Liebscher \\ School of Arts and Social Sciences, University College London
}

\section{In the beginning ...}

'Why waste time? Publish it as it is': these the words of a well-meaning friend when confronted with my future prospect of devoting years of laborious research to an edition of the letter exchange between C.G. Jung and his student, colleague and friend, Erich Neumann. This somewhat naïve but not at all unusual reaction originated in the inability to imagine the scope of such an editorial project at its inception. To impart some insight into the editorial work and process I will outline a number of questions that came to my mind in response to my friend's incredulity.

\section{First, what exactly does one want to publish?}

There was no securely established corpus of letters at the beginning of this project. In Jung's case although most of the letters had been retrieved and at least in later years his secretaries copied his letters for archival purposes, nevertheless there were still documents, for instance official attests or letters written by the secretaries on behalf of Jung, that needed to be located.

In 1973 Aniela Jaffé and Gerhard Adler published a selection of Jung's letters spanning the years 1906 to 1961 (in the following abbreviated as JA), that also included a number of letters from Jung to Neumann (Adler \& Jaffe 1973). Whereas Jaffé was in charge of the German edition it was Adler who oversaw the English one. The publication committee also included Jung's daughter Marianne Niehus-Jung. Known as the Letters, these volumes are widely regarded as the definitive edition of Jung's correspondence. Although Jung himself had given permission for the publication in 1956, the editorial work itself began only after his death in 1962. A year later newspaper advertisements were printed to recall letters from various correspondence partners: after the successful retrieval, the final selection of letters was decided upon in 1970. In her introduction Jaffé stated that the selection criterion hinged on whether a letter either contributed to the further understanding of Jung's psychology or increased the knowledge of Jung's personality (ibid., p. 10).

Notwithstanding the great merits of this edition of the letters the given criterion unfortunately justified a rather personal and random selection, and as such the JA (Jaffe-Adler) does not qualify as a scholarly or critical edition of any sorts. ${ }^{1}$ The only way to publish a

\footnotetext{
1 Sonu Shamdasani eloquently summarised the shortcomings of this edition as follows: 'In 1973 and 1975, a selection of Jung's letters was published, edited by Gerhard Adler, in collaboration with Aniela Jaffé. The editors stated that setting aside routine business letters, from the 1,600 letters written by Jung between the years 1906 and 1961, they selected over 1,000. This gives the impression that approximately two thirds of the letters of Jung's that have survived were published in this volume.
} 
correspondence in a scholarly and satisfying way is to establish the complete body of letters of both correspondence partners and to print them in their entirety. There cannot be a selection or omission of any kind as this would detract from the contextual significance, and hence meaning, of the letters.

In the case of the Jung-Neumann correspondence the JA published seventeen of thirty-nine letters from Jung to Neumann. In total the correspondence as published in the new edition ${ }^{2}$ of the Jung-Neumann letters - The Correspondence of C.G. Jung \& Erich Neumann (2015) hereafter abbreviated as $C J N$ - consists of one hundred and twenty-four documents. Along with Jung's letters to Neumann it contains seven attests or references written by Jung for Neumann, and the letter of condolences from Jung to Julie Neumann. The Neumann documents consist of fifty-eight letters from Neumann to Jung, three letters to Marie-Jeanne Schmid, and three lengthy attachments. ${ }^{3}$ In addition there are ten letters by Marie-Jeanne Schmid and three by Aniela Jaffé which were written on behalf of Jung as his secretaries.

In comparison with Neumann's records it was fairly easy to establish the body of Jung's letters due to the early archival efforts in Zurich. In Neumann's case a substantial number of his letters to Jung had survived, but it soon became obvious that some vital letters from Neumann's early discussions with Jung were missing. Without those even the best introduction would not be able to fill the gaps; hence they needed to be found and secured before the realisation of the project could be envisaged at all.

The story of these allegedly lost letters goes back to Neumann's first time in Zurich between autumn 1933 and May 1934. Neumann left Nazi Germany with his wife and son to settle down in British Mandate Palestine, but stopped on his way for psychological training with Jung in Zurich. There is only one letter from Neumann to Jung from this period [4 N]. Although undated and without address the content reveals that it was written between 27 February 1934 - the date of the publication of Gustav Bally's critique of Jung in the NZZ4 and Neumann's departure in May 1934. The reference to a personal conversation with Tony Wolff makes it clear that the letter was written in Zurich. The letter contains a fierce criticism of Jung's race psychological speculation in 'The State of Psychotherapy Today' 5 , where

Furthermore, the publication of 196 letters of Jung to Freud in 1974 (only seven of which had appeared in the Letters volume) would leave only about 400 unpublished letters. This is seriously misleading. From my researches, I would estimate that the amount of Jung's letters represented in these volumes to be less than ten percent. Moreover, their policy of only publishing Jung's letters and not that of his correspondents effectively decontexualised the letters that they did choose to include. From a comparison of the unpublished letters that I have read, problems in the choice of the letters that the editors selected are apparent. The larger share of the letters that the editors reproduced were from Jung's later years, and indeed, from the period when Aniela Jaffé was his secretary. Furthermore, the editors prioritised letters on religious subjects. Consequently, their edition by no means gives a fully representative portrait of Jung in correspondence.' (Shamdasani 2005, p. 57).

${ }^{3}$ A detailed description of these attachments - $5 N(A), 6 N(A)$, and $8 N(A)$ - follows on p. xx (currently p. 4) of this article.

${ }^{4}$ Bally, Gustav (1934): 'Deutschstämmige Therapie?' ['Therapy of German Descent?'], Neue Zürcher Zeitung, No 343, 27 February 1934.

5 'Zur gegenwärtigen Lage der Psychotherapie', Zentralblatt für Psychotherapie und ihre Grenzgebiete VII/1 (Leipzig 1934), pp. 1-16; English translation as 'The state of psychotherapy today': CW 10, pp. 157-173. 
Jung differentiates - as he did in a similar vein in his 'editorial' of the Zentralblatt as president of the $\mathrm{AAPT}^{6}$ - between a Jewish and an Aryan unconscious.

No reply from Jung to this letter exists as Neumann and Jung decided to discuss their differences in person. At the meeting Jung promised to conduct a correspondence with Neumann about the specifics of a Jewish psychology once Neumann had settled down in Palestine. With this assurance Neumann left Zurich to join his family in Tel Aviv.

When I had a first glance at the body of letters that had survived through the years nothing indicated that Neumann had taken up this question in his correspondence with Jung. There were only a few undated letters from that time but not a substantial discussion of any sort. However there was a significant letter by Jung from 12 August 1934 [7 J] in which Jung apologised for the lack of previous letters due to exhaustion and because, 'Then I had to read through your comprehensive manuscripts! No small matter.' But there was no sign of any manuscripts of that sort in the Jung archive and it seemed as if Jung had referred to an extended version of Neumann's text for the Jüdische Rundschau in $1934 .{ }^{7}$ Only when I went to see the private collection of Neumann's daughter in Jerusalem did I discover some untitled and undated manuscripts. A closer examination revealed the significance of these documents as these were indeed the hitherto unknown attachments of Neumann's letters to Jung from 1934/35. Thus these were consequently able to be published in the JungNeumann correspondence, in conjunction with the cover letters, as $5 N(A), 6 N(A)$, and 8 $N(A)$. These documents contain the actual content of Neumann's discussions with Jung in the '30s, and Jung's letters and replies cannot be understood without these lengthy and difficult texts.

It is very unlikely that Jaffé and Adler knew about these attachments. Like all the subsequent readers of Jung's letter of 22 December 1935 they could not know that this letter was a further direct response to Neumann's attachments. It was in fact only an addendum to Jung's previous letter of 27 April 1935 [15 J], which was the most detailed reply to Neumann's questions and remarks about Jewish psychology. It is therefore somehow puzzling that Jaffé and Adler chose to publish the letter from December 1935 and not this earlier one. There can hardly be any of Jung's letters from the '30s that would more aptly fulfil the criterion of improving the understanding of Jungian psychology as $15 \mathrm{~J}$. But as I have suggested, the most likely reason could be the then unavailability of Neumann's attachments, which are so important for the understanding of Jung's responses.

\section{Second, in what order should one publish the letters?}

As the case of Neumann's Zurich letter shows, the dates of the letters were not all certain, although this problem concerned only the letters from Neumann. Some of his handwritten letters did not have a date or a given location, and I started to sympathise with Aniela Jaffé's description of Neumann, in a letter of 11 September 1956, as 'one of those monsters who do not write a date (or date without a year)' (CJN, p. 321). The establishing of dates and places through a thorough contextualisation was therefore of the uttermost importance.

Besides the attached 'content' letters, which could be linked easily to the respective cover letters, six letters remained undated and the time of their writing needed to be narrowed down in order to place them in chronological sequence. With the exception of $85 \mathrm{~N}$, written from Ascona, probably in 1951, all of those undated letters are from 1934 or 1935 . Their time

\footnotetext{
6 'Editorial', Zentralblatt für Psychotherapie und ihre Grenzgebiete VI/3 (Leipzig) pp. 139-140; again in CW 10, pp. 533-534.

${ }^{7}$ Erich Neumann: Letter to the Jüdische Rundschau regarding 'Die Judenfrage in der Psychotherapie', Jüdische Rundschau, 48, 15 June 1934, p. 5. Republished as Appendix I in CJN, pp. 355-6.
} 
of writing could be established through references to previous or subsequent letters by Jung. Sometimes the mention of an event or publication helped, as in the case of $5 \mathrm{~N}$, where Neumann refers to his rejoinder to Kirsch in the Jüdische Rundschau, the date of which was 15 June 1934. In the case of $8 \mathrm{~N}$ the clue to the time of writing was a letter from Toni Wolff, found in the Neumann archives. In his letter to Jung, Neumann asked for permission to send copies of his letters to Toni Wolff, whom he had previously contacted concerning this question. As the reply from Wolff to Neumann dates 17 November 1934 it was easy to put the letter $8 \mathrm{~N}$ in the correct chronological order of the Jung-Neumann correspondence.

\section{Third, what do these letters actually say?}

Here I am not even referring to the overt content, but to the pragmatic problem of deciphering difficult handwriting. A recurring apology of Neumann vis-a-vis Jung was the state of his handwriting: for instance he wrote in late summer/autumn 1934, 'I don't like to bother you with my barely legible handwriting' (CJN, p. 60). Neumann was aware that the illegibility of his writing placed a significant burden on the patience of his correspondence partners and sometimes used typewriters to make it easier for them. Here he followed a suggestion by Toni Wolff who complained that 'your handwriting is not easily legible and it is quite a job to decipher it' (17 November 1934). Nevertheless a substantial part of Neumann's letters were handwritten and needed to be 'deciphered'.

\section{Fourth, what do these letters say?}

Even when a chronological sequence of letters has been established the dialogue between the correspondence partners remains often vague and enigmatic to an outside reader who does not know the events, persons, or topics discussed. This is where the introduction and annotations come into play for without a proper historical contextualisation a published correspondence will only be of value to a few initiated scholars. In the case of the letter exchange between Jung and Neumann this consideration is especially pertinent as most of the material concerning Neumann was not known before the publication of the correspondence, and the archive material was not even accessible.

\section{Fifth, look, what can go wrong?}

Albeit we should bear in mind that the selective letter edition of $1973^{8}$ served a different purpose from the Jung-Neumann correspondence edition of 2015 the following comparative examples should help to demonstrate why a complete edited compendium of the letters with an extended historical contextualisation is so important.

\section{Omission of names}

The first letter chosen for JA was from 29 January 1934, published in CJN as $3 \mathrm{~J}$. Due to the historical proximity in time, Jaffé and Adler often had to hold back the names of patients or other people mentioned in letters; in that case the client was later identified as Ernst Harms (1895-1974). Harms would eventually become a famous child psychologist in his own right and defend Jung after the war against accusations of anti-Semitism. ${ }^{9}$ The obligatory disguise of names was certainly a problem for the early edition.

This very short letter, in which Jung asked the young Erich Neumann, who had just left NaziGermany in Autumn 1933 and was about to leave for Palestine in the following May, if he would take on Harms as his patient, can help to illustrate the problem that accompanies the lack of a proper contextualisation. The short footnote on Neumann in JA does not explain

\footnotetext{
${ }^{8}$ For this purpose I have consulted the German edition, which is with a few exceptions identical with the English edition.

${ }^{9}$ See Ern(e)st Harms: 'Jung: Defender of Freud and Jews. A chapter of European psychiatric history under the Nazi yoke.' Psychiatric Quarterly 20 (April 1946) pp. 199-230; again in A. Maidenbaum \& S. Martin (1991): Lingering Shadows. Boston: Shambala, pp. 17-49.
} 
why he was in Switzerland in the first place nor does it say anything about the importance of his writings or his position within the Jungian world. 'Since 1935 in Tel Aviv' is all there is to read next to a statement of Neumann's profession as an 'analytical psychologist' and his main publications. And this is not even factually correct as Neumann left Zurich for Tel Aviv in May 1934, following his wife Julie and his son Micha.

\section{Abbreviations of letters}

The next letter in $J A$ is $18 \mathrm{~J}$ written on 22 December 1935 - missing out on seven letters from Jung or documents connected to Jung up to that point. Again a couple of lines are omitted without further explanation. As it turned out one of these refers to the Letters editor himself Gerhard Adler (1904-1988), who was a childhood friend of Neumann from Berlin, and the other to Heinz Westmann (1902-1986), a Jewish analyst whose Eranos lecture of 1936 could not be published due to political reasons. ${ }^{10}$ The omission of the names is unfortunate as Adler and Westmann did indeed play a role in the on-going conversation between Jung and Neumann. As a mutual friend of Neumann and Jung, Adler became an important intermediary figure between them. In 1934 he was the colleague Jung chose to represent his view in the debate about Jewish psychology in the Jüdische Rundschau, a debate that was started by an open letter from James Kirsch and to which Neumann contributed in defence of Jung. Westmann is mentioned by Neumann in the exchange of those days as an example of assimilated Jewry, who had 'with shameless self-abandonment to "sacrifice the collective bond" which is, after all, a symptom of individuation.' He provides the foil against which Neumann could define himself as a Zionist and Jewish Jungian psychologist in British Mandate Palestine.

\section{Missing biographical information}

The next of Jung's letters chosen for JA was dated 4 April 1938 [26 J], written three years later. In the meantime Neumann and his wife had been to Zurich for the second and last time before the war in May/June 1936. Neumann and Jung would not see each other for eleven years until Neumann eventually returned to Switzerland in the summer of 1947 . Why this letter from 1938 had been chosen is not clear and, again, the sparse comments provided do not clarify the situation to which this letter refers, which concerned the case of Margarete Braband-Isaac (1892-1986). By contrast the footnote 334 of the recent Jung-Neumann Correspondence was able to expand this requisite background information about her to almost an entire page. Jung had written to Neumann about her attempts to organise the Jungian psychologists of Palestine: indeed the unpublished correspondence and recent research indicates that Jung regarded Braband-Isaac as one of his main contacts in Palestine at that time. It is important to know about her personal contact with Neumann, especially after the war, when she lived around the corner from Neumann in Tel Aviv, and how she fell into disgrace with Jung and the Zurich circles in the 50s. Her falling-out of favour left Neumann as Jung's main contact in Palestine, later Israel. ${ }^{11}$

The importance of the correspondence partner's view

The next letter in JA is Jung's letter of 19 December 1938 [28 J]. It is a reply to a lengthy letter from Neumann of 5 December [27 N], that Neumann wrote in the aftermath of the pogrom against Jews in Germany of 9 and 10 November 1938 known as 'Crystal Night'.

\footnotetext{
10 The lecture was finally published in 1986 as an addendum to the volume of 1936 . See Westman(n), Heinz: 'Die Erlösungsidee im Judentum.' In: Gestaltung der Erlösungsidee im Judentum und im Protestantismus, complementary volume to Eranos Yearbook 1936, ed. R. Ritsema, Ascona: Eranos Foundation, pp. 33-110.

11 See Liebscher, 'German Emigré Psychologists in Tel Aviv (1934-1958): Max M. Stern and Margarete Braband-Isaac in conflict with Erich Neumann', in: Sarah Marks (ed.): From Moral Treatment to Psychological Therapies: Psychotherapeutics from the York Retreat to the Present Day [forthcoming]; also CJN, p. 137, n. 344.
} 
Neumann reflects about his personal relationship with Germany, to which he has 'too great a debt of gratitude to identify this simply as the symptoms of its schizophrenic episode'. ${ }^{12}$ For Neumann his contact with Jung was of vital importance in order to 'preserve the feeling that there is still a piece of Europe left, even for a Jew'. ${ }^{13}$ He reported about his book project On the Origins and History of Jewish Consciousness, where, despite everything happening around him, he would reflect on the possibilities of a religious renaissance of Judaism. ${ }^{14}$

The concerned and worrying tone of Jung's reply can only be understood if Neumann's previous account is known to the reader. Although the $J A$ establishes the link with the 'Crystal night' it does not explicate what Neumann had written about it: instead only a short passage from his letter is quoted to illustrate the contents of his current book project. Unfortunately the editors of the $J A$ also decided not to reveal the name of Max M. Stern, whose argument with Neumann and consequent falling-out with Jungian Psychology are an important piece of the history of Analytical Psychology in Palestine. ${ }^{15}$

Another example of the shortcomings of any edition such as the $J A$ that publishes only the letters of one correspondence partner is the letter of 5 January 1952 [89 J]. This letter contained Jung's response to Neumann's pre-publication reading of Answer to Job. Hitherto one could only read Jung's argument, without knowing Neumann's objections or suggestions. The same is true for the exchange in 1959 on Jung's chapter 'Late Thoughts' from Memories, Dreams, Reflections (hereafter MDR). The selected letter is from 10 March 1959 [119 J] and has been widely discussed. The CJN provides for the first time the opportunity to read Neumann's point of view, which is vital to an understanding of Jung's argument which had previously led to such speculation of all sorts.

\section{Sixth, what can be revealed through editorial research?}

The letter of 5 January 1952 [89 J] is a good example of what kind of information a scholarly edition can deliver. Besides the discussion of Answer to Job it also reveals some information about Jung's interest in the Kabbalah around the time of his first heart attack in 1944. This is how it is described in MDR - which was mainly compiled by Aniela Jaffé:

I myself was, so it seemed, in the Pardes Rimmonim, the garden of pomegranates, and the wedding of Tifereth with Malchuth was taking place. Or else I was Rabbi Simon ben Jochai, whose wedding in the afterlife was being celebrated. It was the mystic marriage as it appears in the Cabbalistic tradition. I cannot tell you how wonderful it was. I could only think continually, 'Now this is the garden of pomegranates! Now this is the marriage of Malchuth with Tifereth!' I do not know exactly what part I played in it. At bottom it was I myself: I was the marriage. And my beatitude was that of a blissful wedding

(Jung

1962, p. 294)

12 CJN, p. 140.

13 lbid., p. 139

14 Ursprungsgeschichte des jüdischen Bewusstseins [On the origins and history of Jewish consciousness], vol. I: Beiträge zur Tiefenpsychologie des jüdischen Menschen und der Offenbarung [Contributions to the depth-psychology of the Jewish man and to the problem of revelation], vol.II: Der Chassidismus und seine psychologische Bedeutung für das Judentum [Hasidism and its psychological relevance for the Jewry], unpublished typescript (1934-40).

15 See Liebscher, M. 'German Emigré Psychologists in Tel Aviv (1934-1958): Max M. Stern and Margarete Braband-Isaac in conflict with Erich Neumann', in: Sarah Marks (ed.): From Moral Treatment to Psychological Therapies: Psychotherapeutics from the York Retreat to the Present Day [forthcoming]. 
As a letter from Aniela Jaffé to Rivkah Schärf demonstrates, Jung had been studying Kabbalistic literature in the period before his heart attack: in it he thanks Schärf, via Jaffé, for providing him with the texts. ${ }^{16}$ Schärf in return wrote to Jung on 22 May 1944 referring to a discussion between her and Jung, which had taken place before Jung's illness, ${ }^{17}$ about the relation between Tifereth, Jesod, and Malkuth.

This is Jung's letter to Neumann in 1952:

Ouranos and Tethys do not sleep together any more, Kether and Malchuth are separated, the Shekinah in exile; that is the reason for the affliction in God. The mysterium coniunctionis is the concern of man. He is the nymphagōgós of the heavenly marriage. How can man distance himself from this event? He would then be a philosopher, who speaks about God, but not with him. The former would be easy and would give man false security; the latter is difficult and therefore exceptionally unpopular. Precisely that was my lamented fate, therefore it needed a powerful illness to break through my resistance. I am supposed to be beneath and not above everywhere.

pp. 282-3)

(Jung to Neumann in: CJN,

The first volume of Mysterium Coniunctionis (Jung 1955) published in 1955 repeated that argument almost word by word, though Jung corrected the factual errors: Kether was replaced by Tifereth as the spouse of Malchuth, as was, in the footnote, Oceanos as the spouse of Tethys. The nymphagōgós, the bridal guide for previously married man, became a paranymphos, who accompanies the couple that gets married for the first time. However the editors of $J A$ did not address these inconsistencies.

\section{Seventh, where does the editor stand?}

Jaffé and Adler decided to publish twelve of Jung's post-war letters to Neumann. The correspondence was interrupted between 1940 and 1945 after which Neumann sent a letter to establish contact again, together with the manuscript of Depth Psychology and a New Ethic (Neumann 1949). Due to Jung's heart attacks in 1944 and 1946 these first letters were mainly dealt with by Jung's secretary who was at that time Marie-Jeanne Schmid. The first letter from Jung to Neumann is dated 5 August 1946 [37 J] and was also chosen for JA. It was mainly a letter of praise for Neumann's On the Origins and History of Consciousness (Neumann 1949a) which had been sent to Jung previously.

The letter was very dense and gave an ardent impression of Jung's new psychological interests. He informed Neumann about his contacts and discussions with Catholic scholars. In contrast to JA the CJN gives a detailed account of Jung's Catholic contacts (n. 386), which is important as it contrasts with Neumann's return to a sort of 'pure psychology'. On the Protestant side Jung mentioned Hans Schär's study in which psychology and religion are brought together (n. 387). One can only speculate why the reference to Gershom Scholem is omitted in the JA as Scholem was a respected colleague and friend of Neumann, whose invitation to Eranos was partially due to Neumann's intervention. It was Scholem who wrote an obituary after Neumann's unexpected death in 1960. During this period Jung was not only approaching Christian theology on a deeper level, but since 1944 he had also started to intensify his engagement with Jewish mysticism, a field in which Scholem had become the leading expert.

\footnotetext{
16 Jaffé to Schärf, Spring 1944 (unpublished letter).

17 Schärf to Jung, 22 May 1944 (unpublished letter).
} 
The years between 1947 and 1949 were crucial for the relationship between Jung and Neumann. JA rightly chose five letters from those years: 1 July 1947 [52 J], 19 July 1947 [54 J], 17 August 1948 [69 J], 10 December 1948 [72 J], and 28 August 1949 [82 J]. Unfortunately, the selection did not give an account of what was happening in Zurich at this time, and neither do the commentaries. The two letters from July 1947 refer mainly to a discussion between Neumann and Jung with regard to the Ursprungsgeschichte (Neumann 1949a). Neumann boldly used the term 'castration complex' to which Jung objected because of its Freudian connotation and its one-sidedness. He suggested replacing it with the term 'archetype of sacrifice'. Neumann, as can only be seen in his letters, stood his ground and justified the use of the term as being broad enough in its reference. In the introduction to his book one finds a reiteration of this discussion.

On 17 August 1948 [69 J] Jung expressed his joy about Neumann's 1948 Eranos lecture on the mystical man. And the letter of December 1948 [72 J], which was dated, to be accurate, the 10 December 1948, also avoids any reference to the complicated scenario then unfolding in Zurich which cast a shadow over the circles around Jung, if not over Jung himself. The omission of this circumstance and any traces of it in the letter edition can probably be explained by Jaffé's close relationship with some of the people involved.

The affair evolved around the publication of Neumann's manuscripts Depth Psychology and a New Ethic and On the Origins and History of Consciousness. Jung enthusiastically endorsed the publication of both texts and the publisher Rascher agreed, after Jung's intervention, to take them on. Jung wrote an introduction to the latter praising Neumann for continuing where he, the pioneer, had to stop in his efforts. ${ }^{18}$ Neumann's luck went even further when the recently founded C.G. Jung Institute decided to establish a book series and his Origins was chosen to be the first one in the line.

The institute was run by a curatorium under the vice-president, C.A. Meier, whose book on ancient incubation and modern psychotherapy was only second in the Institute publication pipeline. When Neumann spoke at the Eranos conference for the first time in 1948, giving a lecture that had been checked and praised by Jung beforehand, Meier stormed out of the lecture hall in disagreement. A similar negative reaction was reported by another member of the institute's curatorium, Jolande Jacobi. Both of them were at the forefront of criticism when Neumann's book on the New Ethic appeared at the end of 1948. Toni Wolff, R.F.C. Hull, Cary Baynes, and Marie-Jeanne Schmid were amongst many of the Zurich circle who raised their voices against, as they would probably see it, Neumann's attempt to base a new ethic for analytical psychology on a moral demand for an unconditional integration of the shadow.

Though Jung fended off the criticism for a while, he finally gave in when the curatorium voted to dismiss the book On the Origins and History of Consciousness from the series and to replace it with Meier's monograph. It was the very same Meier who subsequently wrote to Neumann informing him of the decision of the curatorium.

Many of the letters from these years are concerned with this issue. Neumann wrote a fuming letter to Jung, albeit he carefully differentiated between Jung, the president of the institute, and Jung, his teacher and friend. But as the letters from the 1950's show, the friendship between these two men never fully recovered from this affair.

Yet none of the selected letters from $J A$ address this topic even though it remained at the centre of the correspondence during these years. There is no doubt that Jaffé knew about

18 C.G. Jung, (1949) 'Vorwort zu Neumann Ursprungsgeschichte des Bewusstseins' transl. by R.F.C. Hull: 'Foreword to Neumann The origins and history of consciousness.' CW 18, pp. 521-522. 
the affair as she was the secretary of the institute at the time. Her closeness to these events, and its main protagonists, might well have influenced the choice of the letters as their publication would not only have shed a bad light on Meier and Jacobi, but also on Liliane Frey, also a member of the curatorium and Jaffé's analyst, and indeed on Jung himself. Jung later even tried to pressurise Neumann into implementing changes to the New Ethic for the English translation by threatening to withhold his promised preface.

Instead of publishing the letters more centrally concerned with these matters in 1948/49 the $J A$ editors decided to choose only Jung's letter from 28 August 1949 [82 J], a short note that criticised Neumann's 1949 lecture for its difficult and obscure style, confirming the prejudices expressed by Jacobi, Meier and others.

Jung's letter of 28 February 1952, chosen for JA, also needs further contextualisation. In this letter [91 J] Jung expressed his view of Neumann's Amor and Psyche. On the psychology of the feminine (Neumann 1952). This letter needs to be read in the aftermath of the publication affair around the New Ethic. In October 1950 Neumann held a course at the Jung Institute entitled 'On the psychology of the feminine: based on the fairy tale Amor and Psyche'. Members of the consortium and the institute used this opportunity to launch another hefty attack against Neumann. In the presence of the students a fierce discussion between staff members, especially C.A. Meier, broke out. When Jung heard about this incident he summoned the main instigators of this attack to Kuesnacht. Aniela Jaffé was present and took a protocol of this meeting of 5 October 1950. Besides Jung and Jaffé the other participants were Marie Louise von Franz, Emma Jung and Liliane Frey. C.A. Meier's absence was noted. This is what Jung had to say about the unjustified attacks against Neumann:

One should not have discussed the problems in public. It is so finely nuanced that it is not possible to sort it out in a discussion. But above all, one can't load these things onto N. in public. One can't load them onto Dr Meier either. [...] Besides, one must not forget that he has been in Palestine on his own for 9 years. When he worked with me back then, many things which you are learning today had not even been uttered. When he left, we did not yet know much that we know today. And besides, we are not dealing with a theory, but a human being. You cannot do this right in the middle of a course. I would like to see the animus in you if you were to be corrected in a lecture. If I had been there, I would have attempted to rectify some things. But I would have said it only once and then shut up. $\mathrm{N}$. is very sensitive, easily gets upset. But he is a creative man. And one should not upset such people. Leave him alone...'

Jaffé Papers)

(Protocol, 5 October 1950. Aniela

The argument brought forward against Neumann can only be partially reconstructed. What becomes clear from the protocol is that Von Franz criticized Neumann for interpreting the fairy-tale from the female psychological point of view, thereby neglecting the context of the fairy-tale in which it is given as a dream of the male character of the novel. In her study $A$ Psychological Study of the Golden Ass of Apuleius she reiterated that argument in support of her view that the novel is about the anima problem of Apuleius and not about the female's process of detachment from the mother (von Franz 1970, p. 77) ${ }^{19}$. So Jung's commentary on Neumann's interpretation of the tale in the letter of February 1952 has to be seen against the background of the hostilities against Neumann that had arisen after the publication of the New Ethic.

${ }^{19}$ p. 70, n. 1. 
During Neumann's lifetime Jaffé was one of his closest allies in Zurich. After another argument with Jolande Jacobi at the institute in 1959 he wrote a damning letter to Jaffé. Here, Neumann explained his wish not to lecture in Zurich any more. The letter was a reply to Jaffé's attempt to emphasize Neumann's importance for Zurich, especially for the institute and the club. She had written about her impression that the general appreciation that Neumann received by the members would not be reciprocated by him:

Perhaps it is due to past experiences that even today you find yourself in a sort of defensive position in Zurich, and one sometimes gets the impression that you operate according to the principle: 'Attack is the best form of defence'. That has a remarkably divisive effect on your audience. Two camps immediately form: pro Neumann and contra Neumann - a fact which is then, of course, for the most part ignored and not discussed.

\section{Neumann Papers)}

(Jaffé to Neumann, 24 October 1959.

Calling Jaffé naïve, Neumann set out to affirm a more balanced view of his relationship with Zurich over the last decade, asserting that there would be no sympathetic community waiting for him in Zurich or Ascona. This ignorance of those Jungian psychotherapists would have tragic consequences, as he would put his fingers on wounds and problems that needed discussion in order for analytical psychology to survive. ${ }^{20}$ Neumann concluded in his letter that he would be prepared to forget the past insults by Jung, Jacobi, Meier and Frey for the sake of the cause, but his opinion would be side-lined. ${ }^{21}$ And his final verdict sounds devastating:

You know, I put up with some things from C.G. which I am still amazed at today, but at least I know who he is in spite of this and in relation to me. I do not have the feeling that the same is required of me in relation to the Zurichers.

undated letter)

(Neumann to Jaffé,

Aniela Jaffé was herself part of this Zurich circle and her selection of Jung's letters to Neumann was not only informed by her personal friendship with Erich and Julie Neumann, but also by her friendship or acquaintance with his opponents with whom she needed to work on a daily basis. In spite of this personal involvement the first attempt to publish Neumann's letter in the 1980's saw Aniela Jaffé as the editor, assisted by Julie Neumann and Robert Hinshaw. ${ }^{22}$ Due to the unexpected death of Julie Neumann in 1985 the project was delayed and finally abandoned.

\section{There is a season...}

It is hardly news that a complete edition such as the JNC has a big advantage over a publication project of selected letters such as the JA edition. But without any doubt the $J A$ paved the way for later publications of Jung's correspondence. Aniela Jaffé and Gerhard Adler were part of the historical events unfolding, which provided them with an unmediated personal account that today's editors lack. But this personal involvement also limited their

\footnotetext{
${ }^{20}$ Neumann to Jaffé, undated letter, written around late October/November 1959 [NP]: 'Even more, behind the Eranos work, there is much more inner inspirational experience; the system is, in part, difficult work which seems necessary for me, and whether Analytical Psychology will survive depends in part, I sometimes fear, on this.'

21 Ibid: 'A lunch with Frau Dr Frey and Brunner belongs, as kind as they are, in the same category. I have tried hard - for the sake of the cause - to forget the old insults of C.G., Jacobi, Meier and Frey which does not come easily to someone like me.'

22 Personal information from Robert Hinshaw.
} 
access to source material from historical witnesses who, for instance, they had not befriended or were not in contact with. This prevented them from taking a wider perspective and overview, and meant that at times they placed personal sensitivities over historical factuality. This is a problem the editor of today does not have to face. A broader picture emerges, certainly with gaps and errors, but one can at least be confident that future scholars will correct any shortcomings.

'Don't be down-hearted by our inevitable ignorances', I said more to myself than to my friend, and got down to work.

\section{References}

Adler, G. \& Jaffe, A. (eds.) (1973). Letters Vol. I: 1906-50; Vol. II: 1951-61, trans. R.F.C. Hull. Princeton: Princeton University Press.

Jung, C. G. (1955). Mysterium Coniunctionis. CW 14. (1962). Memories, Dreams, Reflections. London: Routledge.

Liebscher, M. (2015). Analytical Psychology in Exile. The Correspondence of C.G. Jung \& Erich Neumann, trans. H. McCartney. Princeton: Princeton University Press.

Neumann, E. (1949). Tiefenpsychologie und Neue Ethik. Zurich: Rascher. English edition (1969): Depth psychology and a new ethic, trans. E. Rolfe. London: Hodder \& Stoughton. Reprint (1990): Massachusetts: Shambhala.

---- (1949a). Ursprungsgeschichte des Bewusstseins. Zurich: Rascher. English edition (1954) The Origins and History of Consciousness, trans. R.F.C. Hull. Princeton: Princeton University Press.

----- (1952). 'Eros und Psyche. Ein Beitrag zur seelischen Entwicklung des Weiblichen' in: Apuleius, Amor und Psyche. Zurich: Rascher. English edition (1956): 'The psychic development of the feminine: a commentary on the tale by Apuleius', trans. R. Manheim, in: Apuleius Amor and Psyche. New York: Pantheon Books, .

Shamdasani, S. (2005). Jung Stripped Bare: By His Biographers, Even. London: Karnac.

von Franz, M-L. (1970). A Psychological Interpretation of the Golden Ass of Apuleius. New York: Spring Publications. 